\title{
"THE TEREK COSSACK HOST CLEANED OUT THE NATIVE VILLAGES FROM THE INFECTION WITH THEIR OWN HANDS": GORSKO-MOZDOK REGIMENTS IN THE RANKS OF THE ARMED FORCES OF THE SOUTH OF RUSSIA IN THE EARLY 1919
}

\author{
Ruslan G. Gagkuev \\ Institute of Russian History of the Russian Academy of Sciences, Moscow, Russian Federation
}

Svetlana G. Shilova

Moscow State University of Psychology and Education, Moscow, Russian Federation

\begin{abstract}
Introduction. The article focuses on the creation of Gorsko-Mozdock regiments of the Terek Cossack Host in the Early 1919 and their subsequent participation in combat operations. The article provides an overview of related historical literature and underlines the importance of further research into the history of the Terek Cossack Host during the Civil War and publication of historical sources. The introduction provides a detailed account of how Terek Cossacks were drafted to the Armed Forces of the South of Russia, and touches upon the difficulties associated with mobilization (not enough officers, undermanning, shortage of weapons and typhus outbreak). Materials. The article introduces a previously unavailable historical source - the order of Terek Cossack Host Mozdock division Ataman Yesaul S.N. Portyanko dated January 17, 1919 on the commencement of mobilization and formation of Cossack regiments. Analysis. The order demonstrates overly optimistic expectations of the Cossack leadership regarding the support of the local population and mobilization results. In real life, fast implementation of the command's plans proved to be impossible due to the situation in Cossack stanitsas. The document shows the Cossack command's commitment to mobilize all available resources in order to defeat the Soviet power. Results. The article sums up the considerations by pointing out that during the Civil War the majority of the Terek Cossack Host opposed the Soviet power and supplied considerable human resources to the Armed Forces of the South of Russia. Despite the aforementioned difficulties caused by the situation in the region, the formation of Cossack regiments went rather well, and soon these regiments were dispatched to the front. The efforts undertaken by the Terek Cossack Host in the war against the Soviet power in 1919-1920 show the Cossacks' unwavering commitment to give their all to victory. Upon the evacuation of the Armed Forces of the South of Russia from the Black Sea coast to the Crimea, Terek Cossacks could no longer hope for reinforcement and were incorporated into other White military units.

Key words: Civil War in Russia, Terek Cossack Host, Gorsko-Mozdock regiments, Armed Forces of the South of Russia, military building, mobilization.

Citation. Gagkuev R.G., Shilova S.G. "The Terek Cossack Host Cleaned out the Native Villages from the Infection with Their Own Hands": Gorsko-Mozdok Regiments in the Ranks of the Armed Forces of the South of 9 Russia in the Early 1919. Vestnik Volgogradskogo gosudarstvennogo universiteta. Seriya 4. Istoriya. ¿ Regionovedenie. Mezhdunarodnye otnosheniya [Science Journal of Volgograd State University. History. Area Studies. International Relations], 2019, vol. 24, no. 4, pp. 84-92. (in Russian). DOI: https://doi.org/10.15688/ jvolsu4.2019.4.7
\end{abstract}




\title{
«ТЕРСКОЕ ВОЙСКО СОБСТВЕННЫМИ РУКАМИ ВЫЧИСТИЛО РОДНЫЕ СТАНИЦЫ ОТ ЗАРАЗЫ»: ГОРСКО-МОЗДОКСКИЕ ПОЛКИ В РЯДАХ ВСЮР В НАЧАЛЕ 1919 ГОДА
}

\author{
Руслан Григорьевич Гагкуев \\ Институт российской истории РАН, г. Москва, Российская Федерация
}

Светлана Геннадьевна Шилова

Московский государственный психолого-педагогический университет, г. Москва, Российская Федерация

Аннотация. Статья рассказывает о создании Горско-Моздокских полков Терского казачьего войска в начале 1919 г. и их последующем участии в боевых действиях. Приведен краткий обзор историографии по данному вопросу, сформулирована важность дальнейшего изучения истории Терского казачьего войска в годы Гражданской войны и публикации исторических источников. Во вступительной части подробно рассказывается об обстоятельствах призыва терских казаков в ряды Вооруженных сил Юга России (ВСЮР), возникших в связи с мобилизацией сложностях (отсутствием достаточного количества офицеров, некомплект личного состава, отсутствие необходимого вооружения и эпидемии тифа). В публикации вводится в научный оборот недоступный ранее исторический источник - приказ атамана Моздокского отдела Терского казачьего войска есаула С.Н. Портянко от 17 января 1919 г. о начале мобилизации и создании казачьих полков. На примере приказа видны чрезвычайно оптимистические расчеты казачьего командования на поддержку населения и соответствующие результаты мобилизации. Реальность показала невозможность быстрой реализации планов командования с учетом ситуации в казачьих станицах. Документ показывает готовность казачьего командования мобилизовать все силы для достижения победы в борьбе с советской властью. При подведении итогов указано, что Терское казачье войско в годы Гражданской войны в своем большинстве выступило противником советской власти и дало немалые пополнения ВСЮР. Несмотря на указанные сложности, связанные с обстановкой в регионе, в войске в целом успешно проходило формирование казачьих полков, выдвинутых вскоре на фронт. Усилия Терского казачьего войска для борьбы с советской властью в 1919-1920 гг. характеризуются чрезвычайным напряжением сил для победы в войне. После эвакуации ВСЮР с Черноморского побережья в Крым терские казаки, лишившиеся возможности пополнения, были включены в состав других белых частей. Авторский вклад в создание статьи произведен авторами в равных долях. При написании материала Р.Г. Гагкуевым и С.Г. Шиловой проанализирована источниковая база и историография вопроса, подготовлен к публикации исторический источник из Российского государственного военного архива, сделаны примечания и комментарии к публикации.

Ключевые слова: Гражданская война в России, Терское казачье войско, Горско-Моздокские полки, вооруженные силы Юга России, военное строительство, мобилизация.

Цитирование. Гагкуев Р. Г., Шилова С. Г. «Терское войско собственными руками вычистило родные станицы от заразы»: Горско-Моздокские полки в рядах ВСЮР в начале 1919 года // Вестник Волгоградского государственного университета. Серия 4, История. Регионоведение. Международные отношения. - 2019. T. 24, № 4. - C. 84-92. - DOI: https://doi.org/10.15688/jvolsu4.2019.4.7

Введение. Участие терских казаков в Гражданской войне наименее освещено в сравнении с другими казачьими войсками Юга России. За последнее десятилетие вышел ряд исследований и публикаций источников [8;13], вносящих существенный вклад в изучение этой проблематики. Первые подробные публикации о военно-политической истории и военном строительстве терцев в годы Граждан- ской войны появились в середине 2000-х годов $[1 ; 2]$. Аспекты военного строительства терцев были рассмотрены в ряде статей, при изучении других аспектов Гражданской войны или при освещении участия в ней казачества Юга России в целом $[14 ; 16]$. Вопросы военно-политического и идеологического противостояния на Тереке в годы Гражданской войны изложены в работах питерского исто- 
рика В.Б. Лобанова [5; 6]. Наконец, наиболее полным исследованием военных аспектов участия терских казаков в Гражданской войне стала диссертационная работа С. Пыльцына, прошедшая защиту в 2019 году [11].

Вместе с тем, несмотря на определенные успехи в изучении темы Терского казачества в Гражданской войне, она нуждается в дальнейшей разработке. Перспективы ее исследования зависят не только от уточнения отдельных вопросов, связанных с военно-политической историей терского казачества и его участием в Гражданской войне. Не менее важно и рассмотрение его истории в этот период во взаимосвязи с действиями других казачьих войск Юга России.

Материалы. Немаловажно, что ряд важных источников по истории Терского казачьего войска по-прежнему остается не опубликованным. Так, в Государственном архиве Российской Федерации хранится несколько томов рукописи воспоминаний терского казака Г.С. Хутиева «На Тереке в 19181920 гг. Терское казачество в Гражданской войне». Введение ее в научный оборот существенно дополнит наши представления о происходивших в эти годы на Тереке событиях. Это же относится и к другим, менее объемным, но не менее интересным источникам по военной и военно-политической истории. Полный текст одного из таких публикуется в данной статье и вносит некоторые дополнения в вопросы военного строительства терцев в начале 1919 года.

Анализ. В годы Гражданской войны в результате тотальной мобилизации терские казаки выставили на фронт против Красной армии четыре дивизии, четыре пластунские бригады, четырнадцать батарей и один дивизион, с названием «терские конные» или «терские казачьи» $[11$, с. 244].

В состав этих частей входили и воссозданные в Терском казачьем войске старые полки русской армии. Одним из таких полков, восстановленных в 1919 г. в рядах Вооруженных сил Юга России (ВСЮР), был ГорскоМоздокский полк (подробнее см.: [14; 15; 11, c. 109-116]), имевший богатые традиции, уходящие корнями в историю терцев. Комплектовавшийся на территории Моздокского отдела Терской области, в годы Первой миро- вой войны полк воевал в составе трех очередей ${ }^{1}$. Благодаря тому, что полк формировался постанично, служившие в нем казаки хорошо знали друг друга (нередко это были соседи или близкие родственники). С развалом русского фронта Первой мировой войны в конце 1917 г. терские казачьи полки вернулись в родные станицы Моздокского отдела.

Контроль над почти всей территорией Терской области был установлен ВСЮР к февралю 1919 года. Заняв территорию войска, «белые» «получили надежного союзника в лице терского казачества» [6, с. 400]. В Терской области была восстановлена власть казачьего войскового правительства. 10 января 1919 г. $^{2}$ главнокомандующим войсками Терско-Дагестанского края был назначен генерал-лейтенант В.П. Ляхов, непосредственно подчинявшийся главкому ВСЮР генераллейтенанту А.И. Деникину и Особому совещанию [6, с. 291].

Одним из первых своих приказов от 16 января 1919 г. Ляхов восстановил должности атаманов территориальных отделов войска. В докладе главкому ВСЮР генерал-лейтенанту А.И. Деникину о своей деятельности в крае, Ляхов среди прочего сообщал, что приступил к формированию 2-й Терской казачьей дивизии, в состав которой помимо 2-го Терского казачьего полка входили три Горско-Моздокских. Преемственность возрождаемых Горско-Моздокских полков русской армии, их вековые традиции в своем слове к офицерам и казакам в марте 1919 г. особо подчеркивал полковник Ф.Е. Головко, командир 3-го Горско-Моздокского полка: «[...Вос] создадим славное прошлое полка и передадим его нашим детям и внукам в таком виде, как давали нам наши отцы и деды» $[7$, л. 7 об.].

В приказе по Моздокскому отделу № 1 от 17 января 1919 г. говорилось о формировании 1-го, 2-го и 3-го Горско-Моздокских полков [4, с. 89; 11, с. 109]. Из мобилизованных терцев предполагалось порайонно сформировать несколько казачьих полков трех очередей. Из казаков станиц Вознесенская, Государственная, Екатериноградская, Курская, Луковская, Новоосетинская, Павлодольская, Приближная, Прохладная, Солдатская, Терская и Черноярская комплектовались 1-й, 2-й и 3-й Горско-Моздокские конные полки. Каждый из полков попол- 
нялся терцами из полковых округов, границы которых совпадали с границами казачьих отделов (правила, применяемые в старой русской армии, казаки пытались соблюдать и в годы Гражданской войны) [11, с. 156].

Командиром 1-го Горско-Моздокского конного полка с середины марта был полковник Ф.П. Заболоцкий. Полк комплектовался из казаков присяг 1911-1918 гг. в станице Прохладной. Формирование 2-го Горско-Моздокского конного полка проходило в станице Екатеринодарской, во главе с полковником С.Н. Аландером. В полк зачислялись казаки присяг 1903-1910 годов. В станице Луковской полковником Ф.Е. Головко велось создание 3-го Горско-Моздокского конного полка, в который зачислялись казаки 35-45 лет (присяга 1893-1902 гг.) [7, л. 7 об.]. Внутри 3-го полка рядовые казаки одной, двух или трех станиц образовывали одну сотню. Например, 1-ю сотню составили казаки Терской станицы, 2-ю уроженцы Луковской и Курской, 3-ю - казаки Новоосетинской, Приближной и Прохладной, 4-ю - Екатериноградской, Павлодольской и Черноярской соответственно (казаки станиц Вознесенской, Государственной и Солдатской разделили между всеми сотнями полка) [7, л. 4 об.]. 3-й Горско-Моздокский полк почти сразу по окончании формирования, ввиду некомплекта личного состава, был сведен в двухсотенный, а 20 мая 1919 г. влит в 1-й Горско-Моздокский полк [11, с. 114].

Иногороднее население казачьих станиц и хуторов сроков службы 1914-1920 гг. было призвано отдельно и составило два запасных батальона. После призыва оно осталось на местах до особо приказания. В Моздокском отделе были также мобилизованы артиллеристы, медицинский и ветеринарный персонал [9, л. 1 об.-2]. При нехватке медицинских и ветеринарных кадров организовывались ускоренные курсы для обучения. Позднее в Терско-Дагестанском крае были также мобилизованы иногородние призывов 1906-1909 годов. Из их числа были созданы два запасных батальона, расквартированные в городах Моздоке и Георгиевске [7, л. 17].

На мобилизацию в станицах и формирование Горско-Моздокских полков командование отвело всего три дня. В начале марта 1919 г. в приказе № 16 по 2-й Терской казачь- ей дивизии указывались полки с датами их окончательного укомплектования: 1-й полк 24 января; 2-й полк - 26 января и 3-й полк 25 января [9, л. 302]. На практике формирование продолжалось около полутора месяцев.

О ходе формирования Горско-Моздокских полков и их готовности к боевым действиям свидетельствует записка начальника штаба Кавказской Добровольческой армии генерал-лейтенанта Я.Д. Юзефовича, поданная 5 февраля 1919 г. начальнику штаба главкома ВСЮР генерал-лейтенанту И.П. Романовскому [3, с. 115]. Юзефович писал о нехватке кадровых офицеров (вакантными оставались должности начальника дивизии и начальника штаба дивизии), личного состава полков (в полках было не более 300-400 шашек) и вооружения (огнестрельного оружия хватало только для половины мобилизованных, а пулеметов в половине полков не было). Материальное обеспечение полков было удручающим ввиду нехватки средств [12, л. 57].

Однако указанные сложности в формировании полков были не единственными. В крае началась повальная эпидемия сыпного тифа, сильно сказавшаяся на численности личного состава полков. Так, на 15 марта 1919 г. в 1-м Горско-Моздокском полку числилось 977 строевых казаков по списку, из которых больных - 329 [12, л. 30], в командировке - 142 , самовольно отлучившихся - 66 и налицо - 440 казаков (всего 45 \%) [12, л. 64]. Полки таяли от эпидемии. Атаманам станиц и отделов приказывалось направлять в полки выздоровевших и самовольно отставивших их казаков. Личный состав полков расходился по станицам, так как в госпиталях не хватало врачей и мест, чтобы принять всех заболевших [12, л. 66]. Согласно рапорту командира 3-го Горско-Моздокского полка полковника Ф.Е. Головко начальнику 2-й Терской казачьей дивизии ${ }^{3}$ от 15 марта 1919 г. в строю в полку числилось 443 казака, из которых заболевших было 230, в командировках - 4 и самовольно отлучившихся - 17 казаков. Налицо было 43 \% личного состава - всего 156 человек [12, л. 66 об.]. Боевой состав четырехсотенного полка составляла всего одна сотня. Головко указывал начдиву, что он неоднократно отправлял телеграммы о возвращении казаков в свою часть «атаманам станиц и ата- 
ману отдела, но до сих пор притока казаков в полк нет». «Докладываю, - писал он, - что полк не имеет ни врача, ни фельдшеров, почему наряду с больными, многие ушли в станицы, симулируя той или другой болезнью. Тем более что больных приходится отправлять по станицам за отсутствием мест в госпитале» [12, л. 66].

Тем не менее, несмотря на указанные сложности (во многом - общие для всех белых армий Юга России), сформированные терские казачьи полки уже весной 1919 г. по мере возвращения больных в строй и укомплектования личным составом были выдвинуты на фронт. Казаки Моздокского отдела Терского казачьего войска в составе Горско-Моздокских полков приняли участие во многих боевых операциях весны 1919 - начала 1920 года. Весной в составе Грозненской группы они участвовали в занятии ВСЮР Чечни и Ингушетии. С середины апреля 1919 г. 2-я Терская казачья дивизия в составе Кубанского корпуса воевала на Царицынском фронте. В августе того же года она была в состоянии переезда в Добровольческую армию. Осенью 1919 г. из-за своей малочисленности 2-я Терская дивизия на основании приказа главнокомандующего ВСЮР была переформирована в бригаду в составе 1-го и 2-го Горско-Моздокских полков и включена в состав вновь сформированной 1-й Терской казачьей дивизии $[10$, с. $333 ; 11$, с. 109]. После эвакуации частей ВСЮР весной 1920 г. в Крым терцы вместе с остатками астраханских казачьих частей были сведены в Отдельную Терско-Астраханскую казачью бригаду. В ее составе терцы принимали участие в боевых действиях вплоть до эвакуации белых сил из Крыма в ноябре 1920 года.

Результаты. Подводя итоги, отметим, что Терское казачье войско в годы Гражданской войны в большей своей части выступило противником советской власти и дало в 19181919 гг. значимые пополнения сначала Добровольческой армии, а затем и ВСЮР. В начале 1919 г. в Терском казачьем войске несмотря на все сложности, связанные с обстановкой в регионе, в целом успешно проходило формирование казачьих полков, выдвинутых вскоре на фронт. Оно велось на традиционных для войска основаниях, но с определенными поправками, учитывающими обстоятельства Гражданской войны и тотальную мобилизацию казаков. Ситуацию внутри Терского войска в 1919-1920 гг. можно охарактеризовать чрезвычайным напряжением его сил для борьбы с советской властью [11, с. 244]. После того как ВСЮР эвакуировались с Черноморского побережья в Крым, сравнительно малочисленные терские части, лишившиеся возможности пополнятся, вошли в состав других белых частей.

Публикуемый документ характеризует начало регулярного строительства войск Терского казачьего войска на второй год Гражданской войны, после ликвидации на его территории советской власти. Машинопись оригинала приказа хранится в фонде 3-го ГорскоМоздокского полка в Российском государственном военном архиве [9, л. 1-3]. Показательно, что первый же приказ назначенного генерал-лейтенантом В.П. Ляховым начальником Моздокского отдела войска есаула С.Н. Портянко касается мобилизации казаков и формирования Горско-Моздокских и Терских полков. Важно, что в приказе подробно расписаны не только сроки призыва, но и порядок явки терцев в полки, вопросы их вооружения и обмундирования, а также обучения военному делу молодых казаков. В ряду других документов о начале военного строительства белых казачьих формирований приказ есаула Портянко дает представление, с одной стороны, о чрезвычайно оптимистических расчетах командования на поддержку населения и соответствующие результаты мобилизации и, как следствие, - численности полков. С другой стороны, этот приказ - наглядный пример готовности казачьего командования напрячь все силы войска для достижения победы в войне с советской властью.

\section{Приказ по Моздокскому отделу}

\section{№ 1}

\section{9 января 1919 г. ст. Прохладная}

\section{$\S 1$}

Приказом командира третьего армейского корпуса от 16-го января с[его] г[ода] за № 8 , я назначен атаманом Моздокского отдела.

Приказываю по всем служебным делам обращаться ко мне. 


\section{$\S 2$}

7-го сего января Великая Могучая Добровольческая армия вошла в пределы нашего родного Терского войска, сметая на своем пути разбойничьи банды красноармейцев и неся с собою мир, порядок и законность. Задача Добровольческой армии - воссоздание единой великой России, не предрешая будущего образа правления, который будет установлен, по окончании борьбы с большевизмом, самим народом через его выборных [представителей]. Борьба еще не окончена и необходимо, чтобы освобожденное усилиями Добровольческой армии из-под ига большевизма Терское войско собственными руками вычистило родные станицы от этой заразы и расчистило почву для мирной жизни и культуры.

По приказу, данному мне командующим войсками Терского и Дагестанского края, объявляю во всех станицах Моздокского отдела мобилизацию казаков присяг от 1918 г. по 1893 г. включительно. Из мобилизационных казаков Моздокского отдела будут сформированы: из конных - 1[-й], 2[-й] и 3-й ГорскоМоздокские и 3[-й], 4-й Терские конные пол-

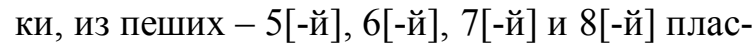
тунские батальоны. Комплектование полков будет порайонно. Станицы: Солдатская, Прохладная, Государственная, Курская, Приближная, Екатериноградская, Черноярская, Новоосетинская, Павлодольская, Луковская, Терская и Вознесенская комплектуют: 1[-й], 2 [-й] и 3-й Горско-Моздокские, а станицы: Стодеревская, Галюгаевская, Ищерская, Наурская и Мекенская - 3[-й] и 4-й Терские конные полки. В 1-й Горско-Моздокский полк из указанного района зачисляются казаки присяг: с 1918 по 1911 г. включительно, во 2-й Горско-Моздокский - с 1910 по 1903 г. включительно и в 3-й Горско-Моздокский с 1902 по 1893 г. включительно. Из района комплектования Терских полков - в 3-й Терский - войдут казаки присяги с 1918 по 1903 г. включительно и в 4-й Терский с 1904 по 1893 г. включительно. Все пешие казаки со всех станиц отдела без распределения по возрастам и районам будут сведены во 2-ю Терскую пешую бригаду по указанию командира бригады.

Bce мобилизованные казаки должны быть одеты и обуты, иметь по три смены белья, снаряжены и вооружены, а конные, поми- мо того, иметь собственных лошадей. В данное исключительное время из конского состава придется взять все, что найдется в станицах, более или менее пригодное к строю. Казаков безлошадных необходимо посадить на лошадей, которые могут быть реквизированы специально избранной для этого в каждой станице комиссией у казаков, не подлежащих мобилизации. На вооружение мобилизованных казаков должно быть взято все имеющееся у казаков и иногородних оружие. Если бы за вооружением мобилизованных оказался излишек оружия, то таковой немедленно представить в управление отдела. Мобилизация в станицах должна быть закончена в трехдневный срок со дня прибытия туда командированных туда для этого офицеров. Все мобилизованные казаки, в присутствии командированных офицеров, при участии станичных фельдшеров, должны быть подвергнуты наружному телесному осмотру и только заведомо негодные к строевой службе должны быть оставлены в станицах, а списки на них представлены ко мне. Более тщательный осмотр будет произведен в полках медицинскими комиссиями.

Все мобилизованные должны быть высланы: подлежащие на укомплектование 1-го Горско-Моздокского полка - в станицу Прохладную, 2-го - в ст[аницу] Екатеринодарскую и 3-го - в станицу Луковскую, 3-го Терского - в станицу Ищерскую и 4-го Терского - в станицу Наурскую, где и должны быть сданы назначенным к тому времени командирам полков. Все же пешие казаки, идущие на сформирование пластунских батальонов, должны быть высланы со всех станиц отдела в гор[од] Моздок в распоряжение командира 2-й Терской пешей бригады.

Одновременно с этим объявляю мобилизацию всего проживающего в станицах, селениях и хуторах отдела иногороднего населения сроком службы 1914, 1915, 1916, 1917, 1918, 1919 и 1920 годов. Все мобилизационные иногородние должны быть одеты в солдатскую форму, иметь исправные сапоги и по три смены белья. Эти мобилизованные до особого распоряжения остаются в станицах и селениях, а мне донести о числе их.

Молодых казаков присяги 1919-1920 гг. немедленно привести к присяге и привлечь к занятиям в станицах, назначив для этого соот- 
ветствующее число инструкторов. Занятия с ними производить ежедневно по три часа до обеда и по два часа после обеда невзирая ни на какую погоду. Для обучения их можно оставить имеющееся в станицах огнестрельное оружие, кроме трехлин[ейных] винтовок, которые должны быть взяты на вооружение мобилизованных. Срок обучения пятинедельный, после чего казаки будут сведены в запасные сотни. Ответственность за обучение возлагается на атаманов станиц и инструкторов.

Довольствие вновь формируемых полков и батальонов впредь до зачисления их в Добровольческую армию относится на счет тех станиц, в которых они будут расположены.

Впоследствии вопрос о вознаграждении и довольствии будет разрешен войсковым начальством.

Для более правильной постановки довольствия необходимо в станицах назначить особых интендантов, которые должны выдавать под квитанцию частей необходимые продукты и фураж.

Медицинские и ветеринарные фельдшера соответствующих возрастов подлежат мобилизации и призыву в полки.

Всех артиллеристов тех же возрастов мобилизовать и в тот же срок направить в гор[од] Моздок в распоряжение назначенного к тому времени командира батареи.

Все вновь избранные должностные лица хотя бы подлежащие по возрасту мобилизации остаются на местах. Из подлежащих мобилизации станичных писарей остаются по одному по строевой и хозяйственной части.

Офицеры и чиновники, как казаки, так и иногородние, в столь тяжелый для войска и России час все без исключения должны стать в ряды войска, по чему предлагаю всем состоящим на службе, в запасе и отставке всех возрастов и чинов, за исключением полных инвалидов, заявить о себе атаманам станиц, а последние должны телеграфировать мне.

Объявляя об этом для исполнения, надеюсь, что испытавшие на себе всю тяжесть власти красноармейских банд, ограбленные, обездоленные и оскорбленные в своих лучших чувствах казачество поймет, наконец, необходимость водворения в крае порядка и законности и всячески будет способствовать всем мероприятиям в этом направлении. Всякому понятно, что только исключительное время вызывает исключительные меры.

Уверен, что переболевшее казачество не захочет повторять старых ошибок и, напрягши на некоторое время свои усилия, очистившись от заразы большевизма, заживет дружной и мирной жизнью и вздохнет свободно и легко.

Подлинный подписал: атаман отдела есаул [C. H.] Портянко С подлинным верно за старшего адъютанта подъесаул [неразборчиво]

\section{ПРИМЕЧАНИЯ}

${ }^{1}$ В 1882 г. было учреждено новое положение о военной службе Терского казачьего войска. Каждый полк Терского войска был разделен на три полка одного названия, например - Горско-Моздокский, но с прибавлением номера очереди. Так, в мирное время на службе находился 1-й полк, а 2-й и 3-й были на льготе. В Первую мировую и в Гражданскую войну воевали полки трех очередей.

2 Даты приведены по Юлианскому календарю (старому стилю), использовавшемуся в 19181920 гг. на территориях, подконтрольных белым на Юге России.

${ }^{3}$ С 14 марта 1919 г. вследствие болезни начдива генерал-лейтенанта Николаева временное командование дивизией принял полковник барон Майдель.

\section{СПИСОК ЛИТЕРАТУРЫ}

1. Гагкуев, Р. Г. Антибольшевистское движение в Терском казачьем войске. Краткий исторический очерк / Р. Г. Гагкуев // Белая Гвардия : альманах. № 8 : Казачество России в Белом движении. М. : Посев, 2005. - С. 102-106.

2. Гагкуев, Р. Г. Горские формирования в составе белых армий Юга России / Р. Г. Гагкуев // Белое дело. 2-й съезд представителей печатных и электронных изданий. Резолюция и материалы научной конференции «Белое дело в гражданской войне в России. 1917-1922 гг.». - М. : Посев, 2005. - С. 77-90.

3. Записка генерал-лейтенанта Я.Д. Юзефовича начальнику штаба главнокомандующего ВСЮР. 05.02.1919 г. / публ. Р. Г. Гагкуева // Белая гвардия : альманах. № 8 : Казачество России в Белом движении. - М. : Посев, 2005. - С. 115-117. 
4. Киреев, Ф. С. Герои и подвиги: уроженцы Осетии в Первой мировой войне / Ф. С. Киреев. Владикавказ : Ир, 2010.-161 с.

5. Лобанов, В. Б. История антибольшевистского движения на Северном Кавказе, 1917-1920 гг.: на материалах Терека и Дагестана / В. Б. Лобанов. СПб. : Полторак, 2013. - 424 с.

6. Лобанов, В. Б. Терек и Дагестан в огне Гражданской войны: Религиозное, военно-политическое и идеологическое противостояние в $1917-$ 1920-х гг. / В. Б. Лобанов ; науч. ред. В. И. Голдин. СПб. : Владимир Даль, 2017. - 483 с.

7. Переписка по 3-му Горско-Моздокскому полку. 21 января - 1 апреля 1919 г. // Российский государственный военный архив. - 1919. - Ф. 40201. Управление 2-й Терской казачьей дивизии. - Оп. 1. Д. 1. -45 л.

8. Писаренко, Д. С. Терское казачество: Три года революции и борьбы. 1917-1920 : материалы и воспоминания / Д. С. Писаренко ; вступ. ст. и коммент. Ф. С. Киреева. - М. : Кучково поле : Военная книга, 2016. -672 с.

9. Приказы 3-го Горско-Моздокского полка о мобилизации казаков и другим административно-хозяйственным вопросам. Список офицеров. 19 января - 23 июля 1919 г. // Российский государственный военный архив. - Ф. 40199 : Терский Горско-Моздокский полк Терского казачьего войска. Оп. 1. - Д. 1. - 196 л.

10. Путеводитель по фондам Белой армии / сост. Н. Д. Егоров, Н. В. Пульченко, Л. М. Чижова. - М. : Вост. лит., 1998. - 526 с.

11. Пыльцын, Ю. С. Антибольшевистские вооруженные формирования Терского казачества в Гражданской войне (октябрь 1917 - 1920 г.) : дис. ... канд. ист. наук : 07.00.02 / Пыльцын Юрий Сергеевич. - Екатеринбург, 2018. - 312 с.

12. Списки офицеров. Сведения о потерях личного состава дивизии // Российский государственный военный архив. - 1919. - Ф. 40201. Управление 2-й Терской казачьей дивизии. - Оп. 1. - Д. 8. - 425 л.

13. Тарганчук, Е. Ф. Жизнь, прожитая не зря / Е. Ф. Тарганчук; вступ. ст. Ф. С. Киреева. - Владикавказ : Терские ведомости, 2016. - 96 с.

14. Шилова, С. Г. Казачьи полки Вооруженных сил Юга России (1917-1920 гг.) / С. Г. Шилова // Военно-исторический журнал. - 2013. - № 1. C. 14-17.

15. Шилова, С. Г. Методы комплектования воинских частей белых армий Юга России, состоящих из коренных народов Северного Кавказа / С. Г. Шилова // Вестник ПСТГУ. -2007. - №4 (25). -С. 46-61.

16. Шилова, С. Г. Организация ветеринарного дела в Вооруженных силах Юга России / С. Г. Шилова // Военно-исторический журнал. - 2013. - № 10. C. $49-54$.

\section{REFERENCES}

1. Gagkuev R.G. Antibolshevistskoe dvizhenie v Terskom kazachyem voyske. Kratkiy istoricheskiy ocherk [Anti-Bolshevist Movement in the Terek Cossack Army. Brief Historical Essay]. Belaya Gvardiya. № 8. Kazachestvo Rossii v Belom dvizhenii [White Guard. No. 8. The Cossacks of Russia in the White Movement]. Moscow, Posev Publ., 2005, pp. 102-106.

2. Gagkuev R.G. Gorskie formirovaniya v sostave belykh armiy Yuga Rossii [Mountain Formations as Part of the White Armies of the South of Russia]. Beloe delo. 2-y syezd predstaviteley pechatnykh $i$ elektronnykh izdaniy. Rezolyutsiya $i$ materialy nauchnoy konferentsii «Beloe delo $v$ grazhdanskoy voyne v Rossii. 1917-1922 gg.» [White Case. $2^{\text {nd }}$ Congress of Representatives of Print and Electronic Publications. The Resolution and Materials of the Scientific Conference "White Case in the Civil War in Russia. 1917-1922"]. Moscow, Posev Publ., 2005, pp. 77-90.

3. Zapiska general-leytenanta Ya.D. Yuzefovicha nachalniku shtaba glavnokomanduyushchego VSYuR. 05.02.1919 g. [Note by Lieutenant-General Ya.D. Yuzefovich to the Chief of Staff of the Commander-in-Chief of the Armed Forces of Southern Russia. May 5, 1919]. Belaya gvardiya: almanakh. № 8: Kazachestvo Rossii v Belom dvizhenii [White Guard. No. 8. The Cossacks of Russia in the White Movement]. Moscow, Posev Publ., 2005, pp. 115-117.

4. Kireev F.S. Geroi i podvigi: urozhentsy Osetii v Pervoy mirovoy voyne [Heroes and Deeds. Natives of Ossetia in the First World War]. Vladikavkaz, Ir Publ., 2010. 161 p.

5. Lobanov V.B. Istoriya antibolshevistskogo dvizheniya na Severnom Kavkaze, 1917-1920 gg.: na materialakh Tereka i Dagestana [History of the Anti-Bolshevik Movement in the North Caucasus, 1917-1920. On the Materials of Terek and Dagestan]. Saint Petersburg, Poltorak Publ., 2013. 424 p.

6. Lobanov V.B. Terek $i$ Dagestan v ogne Grazhdanskoy voyny: Religioznoe, voennopoliticheskoe i ideologicheskoe protivostoyanie v 1917-1920-kh gg. [Terek and Dagestan in the Fire of the Civil War. Religious, Military-Political and Ideological Confrontation in 1917-1920s.]. Saint Petersburg, Vladimir Dal Publ., 2017. 483 p.

7. Perepiska po 3-mu Gorsko-Mozdokskomu polku. 21 yanvarya -1 aprelya $1919 \mathrm{~g}$. [Correspondence on the $3^{\text {rd }}$ Gorsko-Mozdok Regiment. January 21 -April 1, 1919]. Rossiyskiy gosudarstvennyy voennyy arkhiv. Upravlenie 2-y Terskoy kazachyey divizii [Russian State Military Archive. Management of the $2^{\text {nd }}$ Terek Cossack Division], 1919, F. 40201. Upravlenie 2-y Terskoy kazachey divizii [Office of the Terek Cossack Division], Op. 1, D. 1. 451. 
8. Pisarenko D.S. Terskoe kazachestvo: Tri goda revolyutsii $i$ borby. 1917-1920: materialy $i$ vospominaniya [Terek Cossacks. Three Years of Revolution and Struggle. 1917-1920. Materials and Memories]. Moscow, Kuchkovo pole Publ., Voennaya kniga Publ., 2016. 672 p.

9. Prikazy 3-go Gorsko-Mozdokskogo polka o mobilizatsii kazakov i drugim administrativnokhozyaystvennym voprosam. Spisok ofitserov. 19 yanvarya-23 iyulya $1919 \mathrm{~g}$. [Orders of the $3^{\text {rd }}$ GorskoMozdok Regiment on Mobilization of the Cossacks and Other Administrative and Economic Issues. List of Officers. January 19 - July 23, 1919]. Rossiyskiy gosudarstvennyy voennyy arkhiv. Terskiy Gorsko-Mozdokskiy polk Terskogo kazachyego voyska [Russian State Military Archive. Terek Gorsko-Mozdok Regiment of the Terek Cossack Host], F. 40199. Terskiy Gorsko-Mozdokskiypolk Terskogo kazachego voyska [Terek Gorsko-Mozdok Regiment of the Terek Cossack Host], Op. 1, D. 1. 1961.

10. Egorov N.D., Pulchenko N.V., Chizhova L.M. Putevoditel po fondam Beloy armii [Guide to the Funds of the White Army]. Moscow, Vostochnaya literatura Publ., 1998. 526 p.

11. Pyltsyn Yu.S. Antibolshevistskie vooruzhennye formirovaniya Terskogo kazachestva v Grazhdanskoy voyne (oktyabr 1917-1920 g.): dis. ... kand. ist. nauk [Anti-Bolshevist Armed Formations of the Terek Cossacks in the Civil War (October 1917-1920). Cand. hist. sci. diss.]. Ekaterinburg, 2018. 312 p.
12. Spiski ofitserov. Svedeniya o poteryakh lichnogo sostava divizii [Lists of Officers. Information About the Loss of the Division Staff]. Rossiyskiy gosudarstvennyy voennyy arkhiv. Upravlenie 2-y Terskoy kazachyey divizii [Russian State Military Archive. Management of the $2^{\text {nd }}$ Terek Cossack Division], 1919, F. 40201. Upravlenie 2-y Terskoy kazachey divizii [Office of the Terek Cossack Division], Op. 1, D. 8.4251.

13. Targanchuk E.F. Zhizn, prozhitaya ne zrya [Life Lived Not in Vain]. Vladikavkaz, Terskie vedomosti Publ., 2016. 96 p.

14. Shilova S.G. Kazachyi polki Vooruzhennykh sil Yuga Rossii (1917-1920 gg.) [Cossack Regiments of the Armed Forces of the South of Russia (19171920)]. Voenno-istoricheskiy zhurnal [Military Historical Journal], 2013, no. 1, pp. 14-17.

15. Shilova S.G. Metody komplektovaniya voinskikh chastey belykh armiy Yuga Rossii, sostoyashchikh iz korennykh narodov Severnogo Kavkaza [Methods of Recruiting Military Units of the White Armies of the South of Russia Consisting of the Indigenous Peoples of the North Caucasus]. Vestnik PSTGU [St. Tikhon's University Review], 2007, no. 4(25), pp. 46-61.

16. Shilova S.G. Organizatsiya veterinarnogo dela v Vooruzhennykh silakh Yuga Rossii [Organization of Veterinary in the Armed Forces of the South of Russia]. Voenno-istoricheskiy zhurnal [Military Historical Journal], 2013, no. 10, pp. 49-54.

\section{Information about the Authors}

Ruslan G. Gagkuev, Doctor of Sciences (History), Leading Researcher, Institute of Russian History, Russian Academy of Sciences, Dmitriya Ulyanova St., 19, 117292 Moscow, Russian Federation, gagkuev@yandex.ru,https://orcid.org/0000-0002-1413-6684

Svetlana G. Shilova, Candidate of Sciences (History), Associate Professor, Moscow State University of Psychology and Education, Sretenka St., 29, 127051 Moscow, Russian Federation, svetlanashilova@yandex.ru, https://orcid.org/0000-0002-8639-3284

\section{Информация об авторах}

Руслан Григорьевич Гагкуев, доктор исторических наук, ведущий специалист, Институт российской истории РАН, ул. Дмитрия Ульянова, 19, 117292 г. Москва, Российская Федерация, gagkuev@yandex.ru, https://orcid.org/0000-0002-1413-6684

Светлана Геннадьевна Шилова, кандидат исторических наук, доцент, Московский государственный психолого-педагогический университет, ул. Сретенка, 29, 127051 г. Москва, Российская Федерация, svetlanashilova@yandex.ru, https://orcid.org/0000-0002-8639-3284 